\section{Russian military expenditure: what's behind the curtain?}

\section{Vasily Zatsepin}

$\mathrm{M}$

itary budgets as "a visible manifestation of national strategic intentions, priorities, and policies" still are worthy objects for study and monitoring. ${ }^{1}$ In the Cold War era, western economists devoted serious attention to the Soviet economy in general and to Soviet military expenditure in particular. The validity of these efforts is obvious but, for the latter, their effect was mostly contradictory and some times disappointing. ${ }^{2}$ (Statistically, there is still little known about past Soviet military expenditure. ${ }^{3}$ ) With few exceptions, contemporary Russian military expenditure cannot boast of such attention, ${ }^{4}$ even though the United Nations (U.N.), the International Monetary Fund (IMF), the North Atlantic Treaty Organization (NATO), the Stockholm International Peace Research Institute (SIPRI), the International Institute for Strategic Studies (IISS), and others ${ }^{5}$ continue to monitor this subject.

Inside Russia, the topic of military expenditure is usually disregarded by economists and does not receive close scrutiny. Breaking this tradition of relative inattention, since the year 2000 the Moscow-based Institute for the Economy in Transition (IET), an independent research body, has begun to publish annual estimates of Russian military expenditure. ${ }^{6}$ Based on IET's work, this article presents an analysis of Russia's current practice of recording and reporting its military expenditure. It examines, first, Russian military expenditure since 1999 with an emphasis on the current budget year. Second, the underlying budgeting process, defense planning, and other institutional factors are considered. And third, prospects for the future, as announced by high-ranking Russian officials, are reviewed and some problems encountered when researching Russian military expenditure are discussed.

\section{Russian military expenditure}

\section{Definition of military expenditure}

The definition of military expenditure used by IET is based on a framework proposed by the United Nations - the U.N. Standardized Instrument for Reporting Military Expenditures - and resembles that developed by Argentina and Chile with U.N. support. ${ }^{7}$ The functional classification of Russia's federal budget according to its annual Federal Budget Law (budget allocation) and its Federal Budget Execution Law (actual outlays) serves as the base for the evaluation. The main part of military expenditure is concentrated in the National Defense budget function and covers the country's spending on its military atomic program and its armed forces (military and civilian personnel minus retirement pensions; operations and maintenance; procurement; military construction; research and development). The resulting amount is regarded as defense (or direct military) expenditure and is labeled in this article as DEFEX.

Based on this, another measure - labeled $\mathrm{MLEX}_{1}$ - is found by adding indirect military expenditure, taken from a budget division called National Security and Law Enforcement Activity (i.e., troops of the Ministry of Interior, other security bodies, and border service). Also included, from other budget categories, are expenses on civil defense, special construction, and preparation for mobilization of the economy. The total is a close analog to the U.N.'s $G_{1}$ measure, ${ }^{8}$ which also includes civil defense matters. A second aggregate of military expenditure $\left(\mathrm{MILEX}_{2}\right)$ is estimated by adding expenses connected with previous military activity, namely on retirement pensions for military personnel and an appropriate part of the state's Housing Program under which retired military personnel are provided with a dwelling. The MILEX aggregate is an analogue to the U.N.'s $G_{2}$ measure, which in addition to $G_{1}$ includes net pension benefit expenditure. ${ }^{9}$ Figure 1 shows the components of Russian military expenditure.

\section{Short-run spending dynamics}

Defined as described, a uniform time series for the years 1999 to 2004 can be generated (see Table 1; panel A in roubles; panel B as a percentage of Russian GDP). Notwithstanding well-known limitations in comparing military expenditure across countries, ${ }^{10}$ the data in panel C is converted to current U.S. dollars at purchasing power parity (panel D). When considering actual outlays, it is important to know that data about the execution of the federal budget by law become available in Russia only 25 months after its passage. For comparison, panel B also displays SIPRI data.

Current military expenditure

Unfortunately, by changing its budget functional classification in 2005 to accord with the Classification of the Functions of Government (COFOG) of the U.N.'s System of National Accounts and the IMF's Government Finance Statistics Manual 2001, ${ }^{11}$ the Russian government has "spoiled" the uniformity of observed time series. Now civilian-type expenditures of the Ministry of Defense are excluded from the National Defense category and transferred to other ("peaceful”) divisions. In some cases, this produces unexpected (from the standpoint of economics) effects which will be described later. On the plus-side, however, this change shifts the $\mathrm{MILEX}_{2}$ definition used by IET closer to that used by NATO. ${ }^{12}$ 


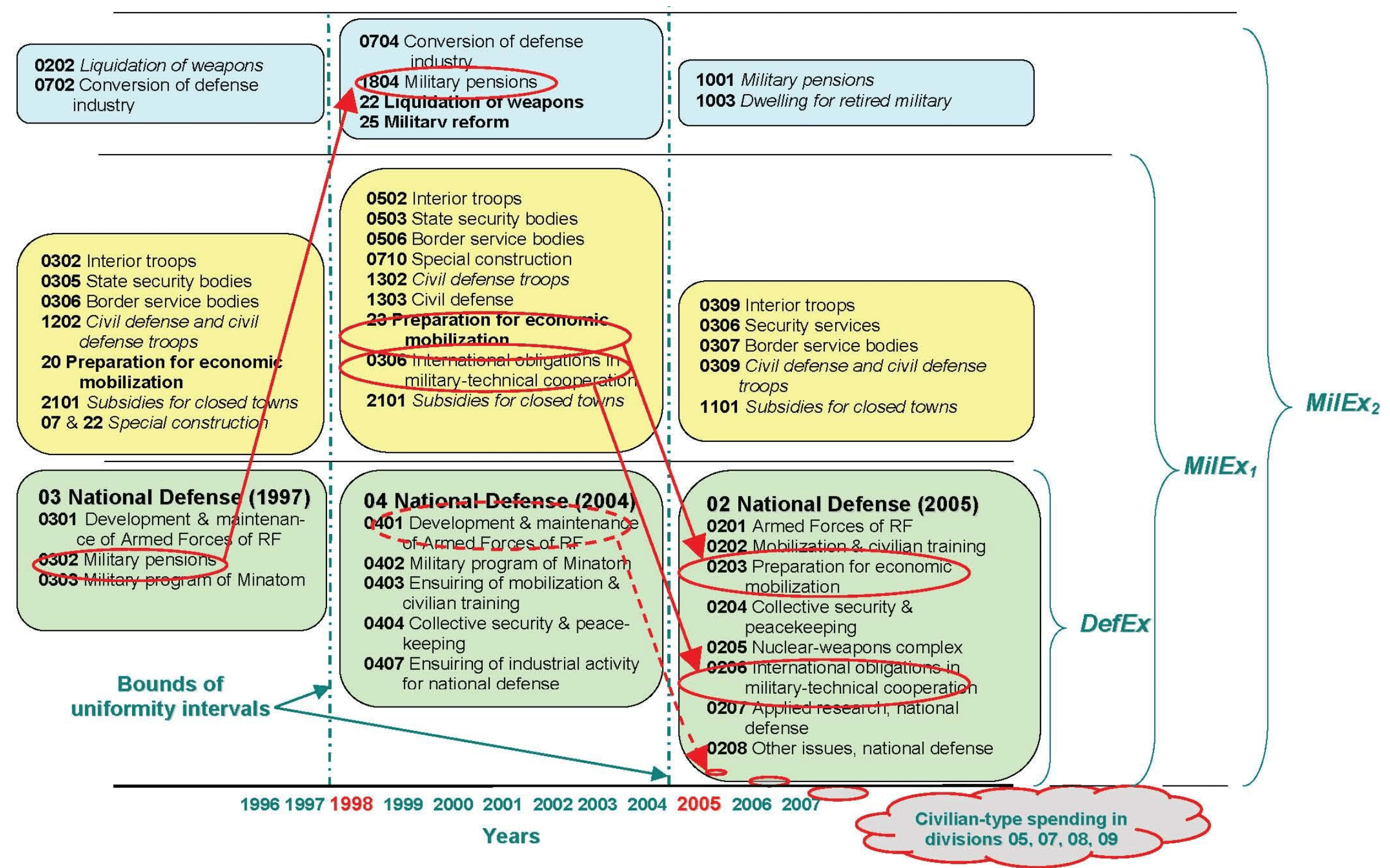

Figure 1: Components of Russian military expenditure since 1995. Source: Russian federal budgets, 1996-2006. ConsultantPlus ${ }^{\circledR}$ database software. Note: Budget division titles and codes of divisions and subdivisions are shown in bold; analytical groups under the codes are in italics. 


\section{Table 1: Russian military expenditure}

Panel A (billions, constant roubles; base year = 1999)

DEFEX (outlays)

DEFEX (budget)

DEFEX (outlays/budget, \%)

DEFEX outlays growth $(1999=100 \%)$

MILEX $_{1}$ (budget)

$\mathrm{MILEX}_{2}$ (budget)

\begin{tabular}{|c|c|c|c|c|c|c|c|c|}
\hline 1999 & 2000 & 2001 & 2002 & 2003 & 2004 & 2005 & 2006 & $2007^{a}$ \\
\hline 115.6 & 139.3 & 154.5 & 159.5 & 169.0 & 172.2 & 194.5 & - & - \\
\hline 93.7 & 152.2 & 133.9 & 153.5 & 168.6 & 171.2 & 193.5 & 198.3 & 222.6 \\
\hline $123 \%$ & $92 \%$ & $115 \%$ & $104 \%$ & $100 \%$ & $101 \%$ & $100 \%$ & - & - \\
\hline $100 \%$ & $121 \%$ & $134 \%$ & $138 \%$ & $146 \%$ & $149 \%$ & $168 \%$ & - & - \\
\hline 128.9 & 196.5 & 176.8 & 190.7 & 216.9 & 218.1 & 239.4 & 252.7 & 291.5 \\
\hline 144.0 & 221.4 & 205.6 & 246.1 & 282.5 & 252.6 & 267.7 & 280.7 & 320.0 \\
\hline 2.4 & 2.6 & 2.8 & 2.7 & 2.7 & 2.6 & 2.7 & - & - \\
\hline 1.9 & 2.9 & 2.4 & 2.6 & 2.7 & 2.6 & 2.7 & 2.7 & 2.6 \\
\hline 2.7 & 3.7 & 3.2 & 3.3 & 3.4 & 3.3 & 3.3 & 3.5 & 3.4 \\
\hline 3.0 & 4.2 & 3.7 & 4.2 & 4.5 & 3.8 & 3.7 & 3.9 & 3.8 \\
\hline 3.4 & 3.7 & 4.1 & 4.3 & 4.3 & 3.9 & 4.3 & 4.3 & - \\
\hline 115.6 & 191.7 & 247.7 & 295.4 & 355.7 & 430.0 & $581.1^{d}$ & - & - \\
\hline 93.7 & 209.4 & 214.7 & 284.2 & 354.9 & 427.4 & 578.4 & 666.0 & 821.2 \\
\hline 128.9 & 270.4 & 283.4 & 353.1 & 456.5 & 544.5 & 715.4 & 848.8 & $1,075.1$ \\
\hline 144.0 & 304.6 & 329.6 & 455.6 & 594.6 & 630.7 & 800.2 & 942.8 & $1,180.5$ \\
\hline 21.9 & 26.8 & 30.2 & 31.9 & 34.2 & 36.2 & 44.4 & - & - \\
\hline 17.7 & 29.3 & 26.2 & 30.7 & 34.1 & 35.9 & 44.2 & 46.4 & 52.7 \\
\hline 24.4 & 37.8 & 34.6 & 38.1 & 43.9 & 45.8 & 54.7 & 59.2 & 68.9 \\
\hline 27.2 & 42.6 & 40.2 & 49.2 & 57.1 & 53.0 & 61.1 & 65.8 & 75.7 \\
\hline 4,823 & 7,306 & 8,944 & 10,831 & 13,243 & 16,752 & 21,598 & 24,380 & 31,220 \\
\hline 172.5 & 137.6 & 116.5 & 115.5 & 113.7 & 118.6 & 119.7 & 112.4 & 109.8 \\
\hline 5.29 & 7.15 & 8.19 & 9.27 & 10.41 & 11.89 & 13.09 & 14.34 & 15.59 \\
\hline
\end{tabular}

Panel B (as percentage of GDP)

DEFEx (outlays)

DEFEx (budget)

$\mathrm{MILEx}_{1}$ (budget)

$\mathrm{MILEX}_{2}$ (budget)

SIPRI $^{\text {b }}$

Panel C (billions, current roubles) ${ }^{c}$

DEFEX (outlays)

DEFEx (budget)

MILEX $_{1}$ (budget)

$\mathrm{MILEX}_{2}$ (budget)

Panel D (billions, current US \$) ${ }^{e}$

DEFEX (outlays)

DEFEx (budget)

$\mathrm{MILEX}_{1}$ (budget)

$\mathrm{MILEX}_{2}$ (budget)

Auxiliary statistics

GDP ${ }^{\mathrm{f}}$, billions, current roubles

GDP deflator (\%) ${ }^{\mathrm{g}}$

Purchasing power parity, roubles/\$

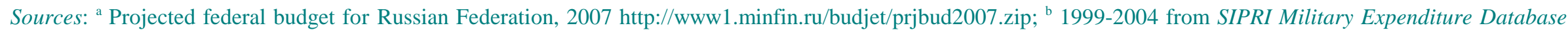

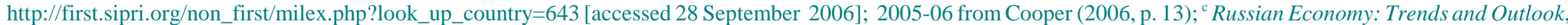

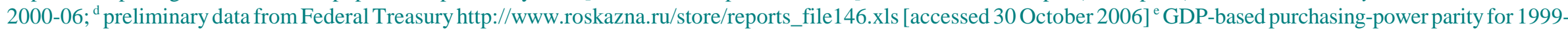

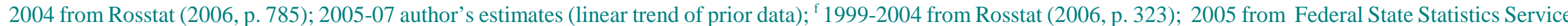

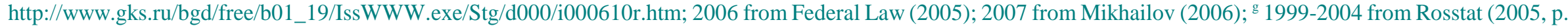
94); 2005-07 from Vasilchuk (2006). 
Table 2: Estimates of transferred civilian-type allocations, 2004-2007

$\begin{array}{llllll} & 2004 & 2005 & 2006 & 2007 \\ \text { Secret civilian-type allocations by division } & \text { (billions, } & \text { current } & \text { roubles) } & \\ \text { 04 National economy } & 0.2 & 0.1 & 0.1 & 3.2 \\ \text { 05 Housing and communal services } & - & - & 1.7 & 2.3 \\ \text { 07 Education } & - & 4.4 & 5.5 & 7.0 \\ \text { 08 Culture, cinematography, mass media } & - & 0.1 & 0.1 & 0.1 \\ \text { 09 Health and sport } & - & 4.0 & 0.1 & 6.9 \\ \text { 11 Interbudgetary transfers } & - & - & - & 3.0 \\ \text { Subtotal for secret allocations } & 0.2 & 8.7 & 12.5 & 22.6 \\ \text { Subtotal for secret allocations (\%GDP) } & 0.00 & 0.04 & 0.05 & 0.07\end{array}$

Explicitly allocated to Ministry of Defense by division (billions, current roubles)

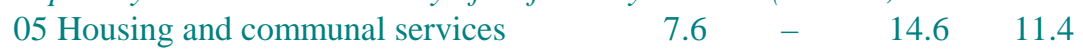
07 Education

08 Culture, cinematography, mass media 09 Health and sport

Subtotal for MoD

Subtotal for MoD (\%GDP)

$\begin{array}{crrr}0.2 & 19.7 & 24.4 & 30.1 \\ - & 1.0 & 1.4 & 1.8 \\ 2.4 & 14.9 & 17.2 & 21.3 \\ 10.3 & 35.6 & 57.7 & 64.6 \\ 0.06 & 0.16 & 0.24 & 0.21 \\ & & & \\ 10.3 & 44.3 & 70.2 & 87.2 \\ 0.06 & 0.20 & 0.29 & 0.28\end{array}$

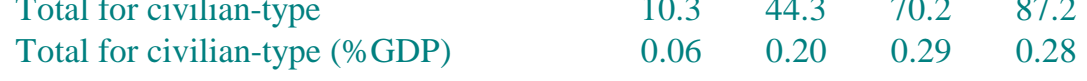

Note: Data for 2004 reallocated to respective divisions of current budgetary classification. Sources: 2004-2006 budget and 2007 budget project data.

Along with the switching to the new budget classification in the 2005 federal budget, a further consolidation of military expenditure in the National Defense division was carried out. This included expenditures for international military technical cooperation programs and preparation for economic mobilization. Moreover, one now finds two new subdivisions: "Applied Research, National Defense” and "Other Issues, National Defense" (see Figure 1). The military expenditure data for 2005-2007 are therefore shown in Table 1 separately from previous periods. Estimates for transferred civilian-type aggregates are given in Table 2 (these estimates are not taken into account in Table 1).

Without doubt, the use in Table 2 of the term "secret" in connection with civiliantype allocations may provoke objections, or at least some questions. Why must these sums be regarded as secret, and if they are secret how it is possible to calculate them? One point is that according to the Law on State Secrets we know for sure about the existence of secret annexes in the budgets which contain data connected to defense procurement, R\&D, and other matters. ${ }^{13}$ For the 2005-2007 budget years, there are 9 secret annexes each year. This is usual budgetary practice in Russia and amounts to about 15-20 percent of the total number of annexes in the last few years' federal budgets; two of the nine are classified as "most secret.” Knowing that there are secret sums, it turns out that one can quite easily calculate them as the difference of the values specified in the budgetary annex containing the distribution of the tota expenditure across the divisions and subdivisions of the functional classification ${ }^{14}$ and the amounts for the same budgetary divisions and subdivisions contained in the annex with the distribution of non-secret allocations. ${ }^{15}$ The procedure is similar to that used for analyses of secret sums in the U.S. defense budget, ${ }^{16}$ but actually simpler due to the explicit structure of secret annexes used in Russia. Regarding the reliability of the estimates in Table 2, note that the values given are lower bounds because allocations to other military bodies (e.g., Interior Ministry troops) are not taken into account so that the actual totals will be substantially higher than reported here.

In this connection it is worth noticing statements made by Victor Zavarzin, chair of the Russian Federation State Duma Defense Committee, which suggest that of the 798 billion roubles of defense expenditure in 2006, 132 billion roubles were hidden in non-military budget divisions. ${ }^{17}$ Including this "hidden” amount in Table 1, panel B for 2006 would increase the estimated defense burden by 0.5 percentage points. (Moreover, according to our budget-based estimates, in 1998 the Russian Ministry of Defense spent about 0.01 percent of GDP on education and health but in 2006 this went up to 0.26 percent. Of course 1998 was disastrous for the Russian finance system, but the data discussed here are for allocations, not outlays.)

Adoption of the new budget classification has led to noticeable discontinuity in the observed time series for Russian military expenditure. Comparability can be restored only by adding the figures shown in Table 2, which would result in a continuation of the nominal use of the old classification. Failing that, the series will be non-uniform.

Openly published U.N. data about the structure of Russian military expenditure in 2005 are shown in Figure 2. However, the data suggest that in 2005 every fifth rouble assigned to armed forces personnel (or 8 percent of total military expenditure) was "unallocated." ${ }^{18}$ Due to the high secrecy level of Russia's federal budget process, as for 2006 it is not possible anymore to estimate the structure of military expenditure from the data supplied by the annual budget laws. Instead, one must rely on imprecise statements, such as that by V. Zavarzin, according to which the capital cost part of Russian defense spending amounted to 40 percent, up from 35-38 percent in $2005 .{ }^{19}$

\section{Behind the curtain}

The federal budget and budgeting process

Russia's budgeting system is still in transition from that used in the former Soviet Union. Although this transition may be in its ultimate phase, the new legal framework 


\section{OPERATING COSTS $67.1 \%$}

CAPITAL COSTS $32.9 \%$

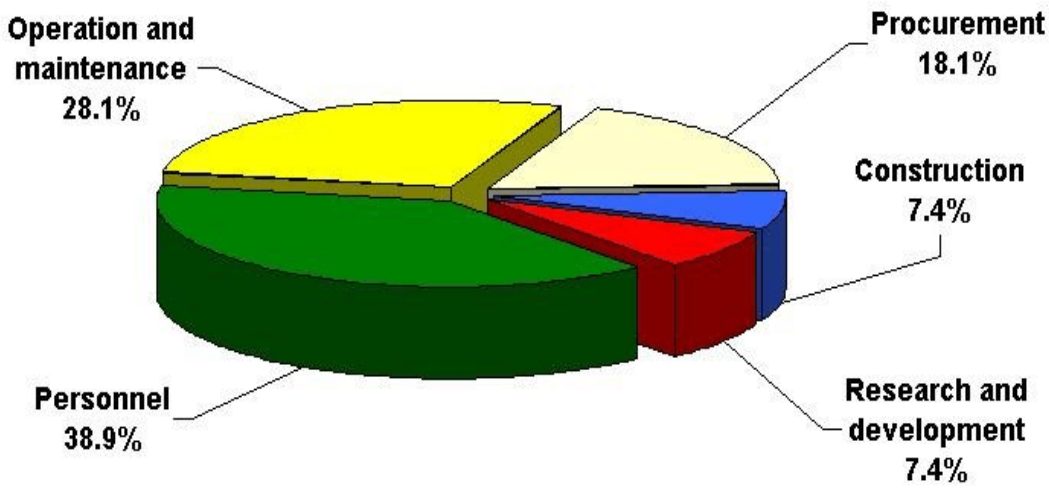

Figure 2: The 2005 structure of Russia’s military expenditure. Source: United Nations (2006).

- the Budget Code that came into force in 2000 - is still subject to annual changes that affects budget management. ${ }^{20}$

The key shortcoming of the federal budget preparation phase is the lack of a formal and openly published budget request by the Ministry of Defense (and other governmental bodies, of course). Consequently the ministry's intentions are subject only to internal government bargaining; outside views cannot be brought to bear on the process. The budget preparation ends with the adoption of a three-year rolling financial plan. The laudable goal is to shorten, to 15-16 months, the ultimate time needed to approve the annual Federal Budget Execution Law (spending authorization) and thereby improve the efficiency of the annual budgetary cycle.

The main actor in the budget approval phase is the Federal Assembly of the Russian Federation. Regrettably, its members cannot effectively carry out the task of budget control because of the presence of a dominant contingent of "soldierpoliticians"21 in both of the relevant defense committees (in the Duma and in the Federation Council). Not only do they lack skills and advanced analytical support in defense budgeting, economics, and accounting but they act "as a kind of lobby for the military circles [rather] than as a tool of democratic control of military and security agencies." 22

Once approved, there are also severe problems with the implementation of the federal budget. Budget execution is known for remarkable, substantial delays. For example, because of the late issuance of the government regulation that implements the federal budget - for the 2006 budget done only at the end of February $2006^{23}-$

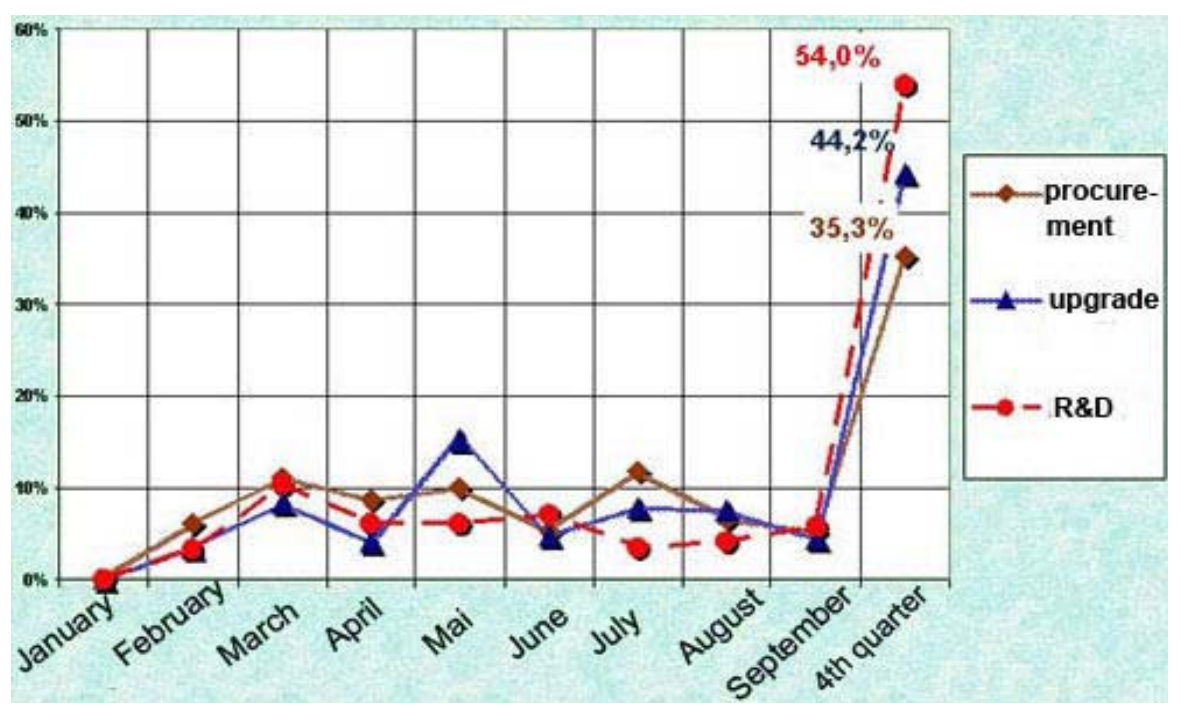

Figure 3: Flow of centralized payments for public procurement contracts by Russian Ministry of Defense in 2005, \% of annual purchase orders volume. Source: Pulin (2006); translated from Russian by the author.

budget payments are skewed toward the end of the budget year. According to statements from the Russian Chamber of Accounts, especially absurd situations arise in the defense sector (see Figure 3).

Another substantial change in the budgetary system involves the previously mentioned adjusting of functional budget classifications to be in line with COFOG, the U.N.'s and IMF's standardized system of national accounts. While this carries implications that may be regarded as positive (e.g., international comparability; removal of non-defense, civilian-type items from the defense budget), it is also true that classified expenditures are now spread across various federal budget divisions unrelated to defense and security, quite an unwelcome effect from the standpoint of defense economists and budget analysts. At a minimum, it raises the question of what were the underlying motives of federal budget developers when placing such expenditures on "secret" lists and then leaving them classified.

\section{Secrecy problem}

According to the already mentioned Law on State Secrets, the most prominent feature of Russia's military expenditure is its potential full secrecy. ${ }^{24}$ Even though the Budget Code limits secrecy to the line-item level, in practice there are entire budget 


\section{Table 3: Secrecy in Russia’s federal expenditures, 2003-07 (\% classified)}

Code and title of division

$\begin{array}{lllll}2003^{\mathrm{b}} & 2004 & 2005 & 2006 & 2007 \\ & & & & \\ & & & & \\ 9.5 & 9.7 & 11.3 & 12.0 & 12.2 \\ \mathrm{n} / \mathrm{a}^{\mathrm{c}} & \mathrm{n} / \mathrm{a} & 3.9 & 6.1 & 7.6 \\ 97.7 & 93.5 & 83.0 & 89.9 & 92.4 \\ - & - & 1.8 & 1.9 & 1.2 \\ \mathrm{n} / \mathrm{a} & \mathrm{n} / \mathrm{a} & 0.1 & 0.1 & 0.7\end{array}$

0115 Other issues in general public services

02 National defense

0201 Armed forces of Russian Federation

0203 Preparation for economic mobilization

0204 Collective security and peacekeeping

0205 Nuclear-weapons complex

0206 International obligations in military-technical cooperation

0207 Applied research, national defense

0208 Other issues, national defense

03 National security and law-enforcement activity

0302 Internal affairs bodies

0303 Interior troops

0306 Security services

0307 Border service bodies

0309 Prevention and liquidation of consequences of emergency situations and natural disasters, civil defense

$\begin{array}{llllll}0311 \text { Applied research, national } & \text { n/a } & \text { n/a } & 76.2 & 67.3 & 63.8\end{array}$ security and law-enforcement activity

$\begin{array}{llllll}0313 \text { Other issues, national security } & \mathrm{n} / \mathrm{a} & \mathrm{n} / \mathrm{a} & 9.0 & 36.4 & 57.4\end{array}$ and law-enforcement activity

$\begin{array}{lllll}100.0 & 98.8 & 97.8 & 96.2 & 97.3\end{array}$

$\begin{array}{lllll}13.0 & 20.2 & 100.0 & 98.8 & 97.5\end{array}$

$\begin{array}{lllll}49.8 & 59.5 & 59.4 & 62.6 & 52.6\end{array}$
Code and title of division

$2003^{\mathrm{b}} 200420052006$

2007

and subdivision ${ }^{\text {a }}$

04 National economy

0410 Applied research, national

economy

0411 Other issues, national economy $\quad$ n/a $\quad$ n/a $\quad 0.1 \quad 0.1 \quad$ -

05 Housing \& communal services $\quad$ n/a $\quad$ n/a $\quad-\quad 4 \quad 4.4 \quad 4.7$

0501 Housing

07 Education

0701 Pre-school education

0702 General education

0704 Secondary professional education-

0705 Retraining \& professional

improvement

0706 Higher professional education $\quad-\quad \begin{array}{lllll}- & & 3.4 & 2.9 & 2.7\end{array}$

$\begin{array}{lllllll}0709 & \text { Other issues, education } \quad- & - & 0.2 & 0.6 & 0.3\end{array}$

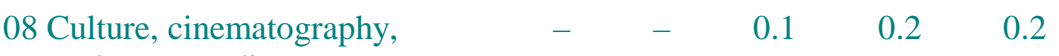
and mass media

0801 Culture

0804 Periodical press and publishing _ _ _ _

houses

0806 Other issues, culture,

cinematography, and mass media

09 Health \& sport

0901 Health

0902 Sport \& physical training

$\begin{array}{lllll}- & - & 3.7 & 3.4 & 3.3 \\ - & - & 4.4 & 3.9 & 3.8\end{array}$

11 Interbudgetary transfers

1101 Financial assistance to other budgets

Note: ${ }^{\text {a }}$ Current budgetary classification; ${ }^{\text {b }}$ data for 2003 and 2004 are reallocated to respective divisions and subdivisions of current budgetary classification; ${ }^{\mathrm{c}}$ direct match in current classification is not available; Sources: 2003-06 budget and 2007 budget project data. 
subdivisions that are fully secret. (The secrecy level itself is regulated not by the Ministry of Defense but, for the most part, by the Ministry of Finance and the Ministry for Economic Development and Trade.) Despite President Putin's May 2004 statement before the Federal Assembly that "a transparent military economy is a necessary condition for reform," ${ }^{25}$ Table 3 shows continuous growth of secret federal expenditure. The reasons for such growth remain hidden, as no official explanatory statements have been made. We only know that for the past two years no substantial changes were made to the official list of data that are considered state secrets. Although additional research is needed, independent observers conjecture that among the main reasons for the observed growth of secret expenditure in the budget is opportunistic behavior by those who stand to personally benefit from the higher remuneration offered for work with classified information. Already it can be shown that civil servants at the Ministry of Finance and the Ministry for Economic Development and Trade face stronger incentives to keep things under the cover of secrecy than the Russian military does (see Table 4).

Table 4: Size of remuneration for work with secret information in Russia

Clearance level

Rated increase to official salary, \% for civil servants for military servants

$\begin{array}{lll}\text { “Of particular importance” } & 50-75 & 25 \\ \text { "Most secret” } & 30-50 & 20 \\ \text { "Secret” } & 10-15 & 10 \\ \text { "Secret” (without formal clearance) } & 5-10 & -\end{array}$

Sources: Regulation (2006b); MOD (2006).

Of course, it is difficult to say what price Russia pays - say in terms of percentage points of GDP lost per one-percent rise in the secret portion of the federal budget but the existence of negative feedback is not doubted.

\section{Defense planning}

Rational defense budgeting is seriously handicapped by deficiencies in defense planning, inherited almost intact from Soviet times. The federal Defense Law ${ }^{26}$ defines the main components of the military planning system. Its main pillars are the Armed Forces Employment Plan, the Force Structure Development Plan, and the State Armament Program, ${ }^{27}$ the first and last constituting the formal basis for defense budgeting. In addition, the Russian General Staff has developed certain long-term plans (see Figure 4 ) ${ }^{28}$ In 2005, this planning system was extended with the adoption of the special Armed Forces Units Provision Comprehensive Program for 2006-

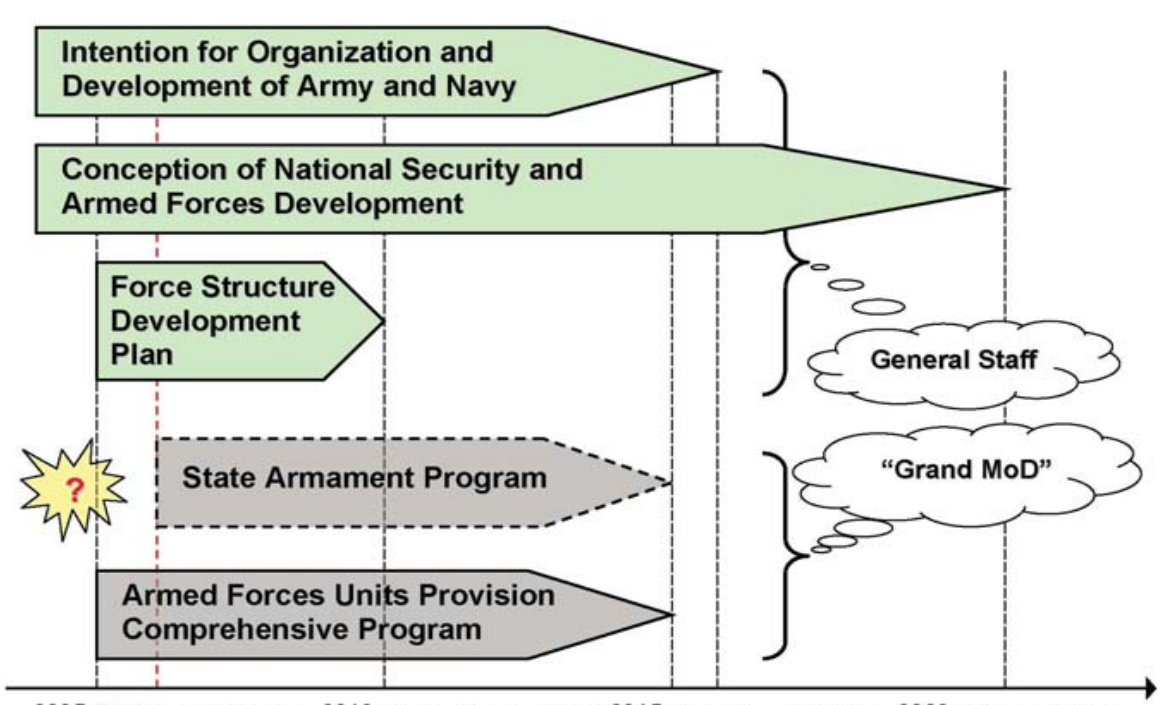

2005200620072008200920102011201220132014201520162017201820192020202120222023 Years

Figure 4: Russian budget-related defense planning. Sources: Federal Law (1996); Baluevskiy (2005); Ivanov (2005).

2015. ${ }^{29}$ But in 2001, the former chief of the Russian General Staff acknowledged that General Staff planning and the State Armament Program were based on incompatible principles, ${ }^{30}$ so that the link between military planning (shown in green on Figure 4) and weapons programming (in grey) may be weak or altogether absent. Any substantial connection of the State Armament Program with defense budgeting must thus be regarded as questionable. ${ }^{31}$

\section{Quasi PPBS}

The State Armament Program goes back to the late 1960s. It was initiated by the Soviet leadership in response to the manifestly successful Planning, Programming, and Budgeting System (PPBS) of the U.S. Department of Defense. Despite the fact that the USSR perished before the first Soviet Armament Program was completed, the Russian Federation continues to use it in practically unaltered form. Yet, as shown in Table 5, the current State Armament Program differs in significant respects from its U.S. counterpart.

Furthermore, from Soviet times to today, those participating in the development of the State Armament Program were unable to negotiate and publish any rules and regulations for it. ${ }^{32}$ Instead of being a means of control over the military-industrial 
(C) www.epsjournal.org.uk - Vol. 2, No. 1 (2007)

Table 5: Comparison of two military programming systems

$\begin{array}{lll} & \text { PPBS (USA) } & \text { State Armament Program (Russia) } \\ \text { Cycle duration, years } & 2 \text { (was 1) } & 5 \\ \text { Depth, }{ }^{b} \text { years } & 4 \text { (was 5) } & 10 \\ \text { Moving time horizon } & \text { Yes } & \text { No } \\ \text { Accountability } & \text { Transparent } & \text { Opaque } \\ \text { Secrecy } & \text { Minimal } & \text { Full }\end{array}$

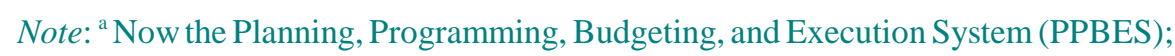
${ }^{\mathrm{b}}$ The current Pentagon budgeting plan has a depth of 6 years. Sources: McCaffery and Jones (2004);Burenok (2004).

complex, the program became a tool for special interest groups to control a considerable share of federal military expenditure. Today, it appears that even the Russian leadership is losing trust in the effectiveness of this inheritance; signs of failure are becoming obvious even for external observers. In fact, the development of the Armed Forces Units Provision Comprehensive Program for 2006-2015 (Figure 4) serves, in essence, as an alternate State Armament Program.

Actors and goals

There are too many actors on the defense management stage in Russia. Forming a virtual “Grand Ministry of Defense,” the size of the country's military expenditure and its structure are determined by the Ministry of Finance and the Ministry of Economic Development and Trade, not by the Ministry of Defense. This results in another source of inefficiency at the highest level of Russian public administration and is vivid evidence of the failure of parliamentary control over the defense and security sector. One effect of this "Grand Ministry of Defense" practice is, for example, the current situation that keeps spending on armed force training at 20-25 percent of the funding level needed to sustain force capabilities, and converting a substantial part of its manpower into overhead.

Back in 2000, the Security Council of the Russian Federation set a goal for the Ministry of Defense to achieve a 50 percent share of capital costs in the defense budget by 2010, following "best international practice." Intended to serve as a performance indicator for the Russian armed forces, this goal was confirmed in July 2005. And in late 2005, the chief of the Russian General Staff stated: "All the world develops according to the outline: about 60 percent is spent on procurement, research and development; and about 30-40 percent on salaries and matters connected with logistics and combat training of forces."33 But even a cursory glance at international practice (see Figure 5) casts grave doubt on the seriousness with which this goal is pursued in practice by Russia's high-ranking officials, even on the priorities they set

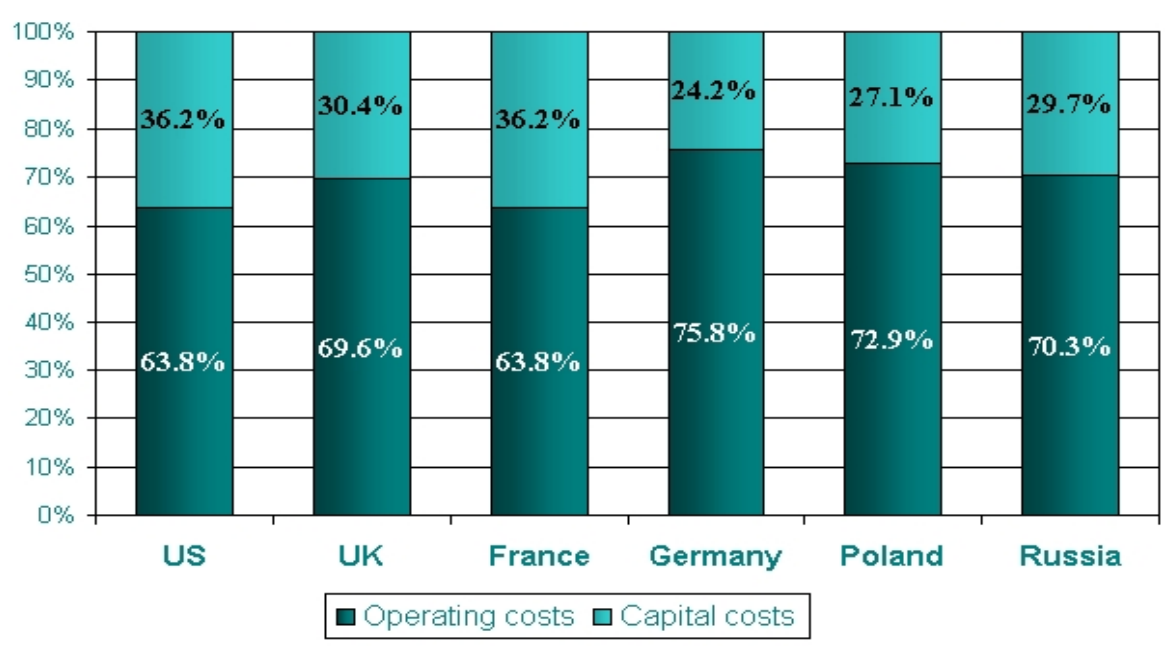

Figure 5: The operating/capital cost structure of military expenditure of a number of countries in 2004. Source: United Nations (2005).

forth, and on the quality of information they use in defense management-related decisionmaking.

Nonetheless, according to a recent statement by the chief of the Defense Economics and Finance Service, the overall movement of Russian defense budgeting can be described as "back to the future.” The former Soviet experience is viewed with envy, nostalgia, and short-sightedness as a valuable classicism, and Russia's prospective military cost structure foresees higher capital cost outlays in future (Figure 6). ${ }^{34}$

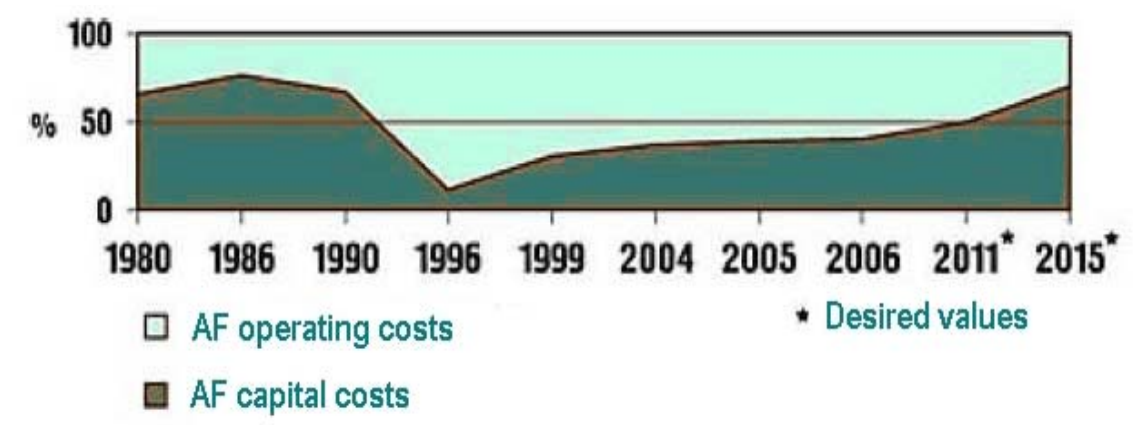

Figure 6: Prospective cost structure of expenditure on Russia's armed forces. Source: Kudelina (2006); translated from Russian by the author. 


\section{Conclusion}

One remaining issue concerns the quality of the time series presented in Table 1. A comparison of IET's with SIPRI's data reveals some differences. Not of critical magnitude, they nonetheless necessitate further data verification to eliminate possible mistakes and simple oversights. More serious efforts will be required to overcome systematic errors, caused for example by the accounting approaches used in the data collection. The IET series can be regarded as a reliable lower bound, however, as our experiments with using different weighted estimates for pensions in paramilitary forces and other adjustments ${ }^{35}$ show the possibility of an increase of about 10 percent in the data for 2005-2007 (at the MiLEX 2 -level). ${ }^{36}$

A second concern regards off-budget and extra-budget military expenditure. Presently, it is impossible to account for these without insider information or a substantial decrease in the level of secrecy in Russia's defense and security sector. Unfortunately, as Russia's public administration reform appears to have come to a stop, a full release of Ministry of Defense budget requests and annual reports and accounts does not appear imminent.

Russia's defense management is a case of government failure, ${ }^{37}$ largely on account of limited information and limited control over bureaucracy (e.g., undue secrecy, lack of quality statistics, and questionable priority setting in the security sector). Failures imposed by the political process were not the focus of this article but my view on this matter is that the successful erection of a so-called "power vertical" does not offer much hope for democratic control of the defense and security sector and its rational management. Russia finds itself in an institutional trap: one pincer is formed by the secrecy obsession of its high-ranking officials, the other by the vital necessity to manage the country's resources efficiently. As regards the main theme, it will be interesting to research and debate the determinants of Russia's recent military expenditure. Already it is widely acknowledged that they are mainly of an internal nature and not connected to external threat levels. ${ }^{38}$

As to the near-term future, it is safe to predict that the current year's federal budget will be increased more than once. For example, lack of fuel for combat training will be excused by "unplanned” price growth (rather than acknowledged as intentional budget policy) and result in higher-than-planned outlays. Also, it seems very likely that most procurement outlays will again be executed in the last quarter of the year. And the secrecy level in Russia's federal budget is likely to grow as well, at least until 2008 when, one hopes, a newly elected president may change Russia's budgetary ways.

Notes

Vasily Zatsepin is with the Department for Military Economics at the Institute for the Economy in Transition, Moscow, Russia, and can be reached at zatsepin@iet.ru. He thanks the editors and an anonymous reviewer for helpful comments.

1. Crane, et al. (2005, p. 91).

2. Rosefielde (2005).

3. Harrison (2003).

4. For example, Cooper (2006), Fontanel (2003).

5. For example, WMEAT (2002).

6. http://www.iet.ru/publication.php?folder-id=44\&category-id=2083\&lang=en.

7. United Nations (2002); CEPAL (2005).

8. CEPAL (2005, p. 63).

9. CEPAL (2005, p. 63).

10. For example, Brzoska (1995).

11. IMF (2002) .

12. WMEAT (2002, p. 194).

13. Law (1993).

14. Annex 8 in (Federal Law, 2005).

15. Annex 46 in (Federal Law, 2005).

16. For example, Kosiak (2006).

17. Matveev (2006).

18. "Unallocated” means not assigned to a particular spending category.

19. See Mikhailov (2006); also see United Nations (2006).

20. Budget Code (1998); Diamond (2002). 


\section{Betz (2002).}

22. Fedorov (2002).

23. Regulation (2006a).

24. Law (1993).

25. Putin (2004)

26. Federal Law (1996).

27. In Russian "Plan primeneniya Vooruzhennykh Sil," "Plan stroitel'stva Vooruzhennykh Sil.”, and “Gosudarstvennaya programma vooruzheniya," respectively.

28. Baluevskiy (2005). The Conception of National Security and Armed Forces Development Until 2021 ("Kontseptsiya natsional'noy bezopasnosti i stroitel'stva Vooruzhennykh sil na period do 2021 goda") and the Intention for Organization and Development of Army and Navy until 2016" ("Zamysel stroitel'stva i razvitiya armii i flota na period do 2016 goda."

29. Ivanov (2005). In Russian "Kompleksnaya programma osnashcheniya soedineniy i voinskikh chastey Vooruzhennykh Sil Rossiyskoy Federatsii na 2006-2015 gody.”

30. Kvashnin (2001).

31. Moreover, the previous Russian armament program finished in 2005, and we now witness a strange one-year pause as the next State Armament Program commences only in 2007.

\section{Burenok (2004).}

33. Chernyak and Gavrilov (2005).

34. Kudelina (2006).

35. For example, separation of military from non-military parts in subdivisions " 0312 Applied Research, National Security and Law Enforcement Activity” and "0313 Other Issues, National Security and Law Enforcement Activity.”
36. Even higher estimates would be achieved by taking into account the appropriate ("military") part of interest charges on government debt (see Brauer, 2004). Of course, this does not change the difficulty of collecting the underlying military expenditure data in the first place.

37. Stiglitz (2000, pp. 9-10).

38. Ovsienko (2005).

\section{References}

Baluevskiy, Yu. 2005. “Tseli i sredstva” [Goals and means]. Rossiyskaya gazeta, No. 13. 26 January 2005, p. 7.

Betz, D.J. 2002. "No Place for a Civilian? Russian Defense Management from Yeltsin to Putin.” Armed Forces and Society, Vol. 28, No. 3, pp. 481-504.

Brauer, J. 2004. "United States Military Expenditure.” Public lecture at The Other Economic Summit (TOES) conference in conjunction with the G8 meeting, Brunswick, GA, 8-10 June 2004.

Brzoska, M. 1995. “World Military Expenditures,” pp. 45-67 in K. Hartley and T. Sandler, eds. Handbook of Defense Economics, vol. 1. Amsterdam: Elsevier.

Budget Code. 1998. Byudzhetnyi kodeks Rossiyskoy Federatsyi No 145-FZ ot 31.07.1998 [Budget Code of Russian Federation \# 145-FZ from 31.07.1998]. ConsultantPlus ${ }^{\circledR}$ database software.

Burenok, V. 2004. "Nauchno-metodicheskie osobennosti razrabotki gosudarstvennoy programmy vooruzheniya” [Scientific and methodological features of the state armament program development]. Voennaya mysl, No. 4, pp. 2-8.

CEPAL. 2005. "Methodology for the Comparison of Military Expenditures." Santiago, Chile: Nationes Unidas, CEPAL.

Chernyak, I. and Yu Gavrilov. 2005. "Yuri Baluevskiy: s NATO voevat' ne sobiraemsya [Yuri Baluevskiy: We are not going fight against NATO]. Rossiyskaya gazeta. No. 245. 1 November 2005, pp. 1, 10.

Cooper, J. 2006. "Military Expenditure in the 2005 and 2006 Federal Budgets of the Russian Federation.” Research note prepared as background to the SIPRI Yearbook chapter on military expenditure, January.

Crane, K., R. Cliff, E. Medeiros, J. Mulvenon, and W. Overholt. 2005. Modernizing China's Military: Opportunities and Constraints. RAND monograph MG-260. Santa Monica, CA: RAND.

Diamond, J. 2002. “The New Russian Budget System: A Critical Assessment and Future Reform Agenda.” OECD Journal on Budgeting, Vol. 2, No. 3, pp. 119147.

Federal Law. 1996. Federal'nyi zakon No. 61-FZ ot 31.05.1996 "Ob oborone” [Federal Law \# 61-FZ from 31.05.1996 “About Defense”]. ConsultantPlus 
database software.

Federal Law. 2005. Federal'nyi zakon No. 189-FZ ot 26.12.2005 “O federal'nom byudzhete na 2006 god” [Federal Law \# 189-FZ from 26.12.2005 “About federal budget for 2006”]. ConsultantPlus ${ }^{\circledR}$ database software.

Fedorov, Y.F. 2002. "Democratic Transformation of the Security Sector in Russia: A Sad Saga of Failure.”Working Paper Series No. 98. Geneva: Centre for the Democratic Control of Armed Forces.

Fontanel, J. 2003. "Les dépenses militaries de la Russie au début du XXI siècle.” Annuaire français de relations internationales, Vol. 4, pp. 568-583.

Harrison, M. 2003. "How Much Did the Soviets Really Spend on Defense? New Evidence From the Close of the Brezhnev Era.” PERSA Working Paper No. 24 (Version 3 January 2003). University of Warwick, Department of Economics.

IMF. 2002. Government Finance Statistics Manual 2001. Washington, DC: International Monetary Fund.

Ivanov, S. 2005. "Vystuplenie Ministra oborony RF S.B. Ivanova na soveshchanii rukovodyashchego sostava Vooruzhennykh Sil Rossiyskoy Federatsii” (Moskwa, 9 noyabrya 2005 goda) [Statement of RF Minister of Defense S.B. Ivanov at a meeting with the leading personnel of the Armed Forces of the Russian Federation, Moscow, 9 November, 2005]. Krasnaya zvezda, No. 208. 11 November 2005, p. 3.

Kosiak, S. 2006. "Classified Funding in the FY 2007 Defense Budget Request.” Washington, DC: Center for Strategic and Budgetary Assessments.

Kudelina, L. 2006. “Oboronnyi byudzhet 2006: prioritety i osobennosti” [Defense budget 2006: priorities and features]. Rossiyskoye voennoye obozrenie, No. 1, pp. 16-20.

Kvashnin, A. 2001. "Perspektivnaya sistema planirovaniya stroitelstva Vooruzhonnykh Sil” [A prospective planning system for Armed Forces structure development]. Voennaya mysl, No. 6, pp. 2-7.

Law. 1993. Zakon ot 21 Iyulya 1993 g. No. 5485-1 "O gosudarstvennoy taine” [Law of 21 July 1993 No. 5485-1 “On State Secrets”]. ConsultantPlus ${ }^{\circledR}$ database software.

McCaffery, J.L. and L.R. Jones. 2004. Budgeting and Financial Management for National Defense. Greenwich: Information Age Publishing.

Matveev, A. 2006. “Oboronnyi byudzhet etogo goda mozhno nazvat' komfortnym” [Defense budget of this year can be called comfortable]. Voenno-promyshlennyi kurier. No. 14, p. 7.

Mikhailov, S. 2006. "Plyusy i minusy oboronnogo byudzheta” [Advantages and shortcomings of defense budgets]. Voenno-promyshlennyi kurier, No. 36, p. 1.

MOD. 2006. Prikaz Ministra oborony RF ot 30 iyunya 2006 g. No. 200 "Poryadok obespecheniya denezhnym dovolstviem voennosluzhashchikh Vooruzhennykh Sil Rossiyskoy Federatsii” [Ministry of Defense Order No. 200 of 30 June 2006 "Procedure for provision with money allowance military servants of Armed
Forces of Russian Federation”]. ConsultantPlus ${ }^{\circledR}$ database software.

Ovsienko, Yu. V. 2005. "The Institutional Barriers to the Modernization of Russia.” Economika i Matematicheskie Metody., Vol. 41, No. 2, pp.44-55 [in Russian].

Pulin, G. 2006. "Novyi format voenno-promyshlennoy komissii” [New format of the military-industrial committee]. Voenno-promyshlennyi kurier, No. 12, p. 6.

Putin, V. 2004. “Poslanie Federal'nomy Sobraniyu Rossiyskoy Federatsii” [Annual Address to the Federal Assembly of the Russian Federation]. Kremlin, Moscow. 26 May 2004.

Regulation. 2006a. Postanovlenie Pravitel'stva Rossiyskoy Federatsii ot 22 fevralya 2006 g. No. 101 “O merakh po realizatsii federalnigo zakona "O federal'nom byudzhete na 2006 god" [Governmental regulation of Russian Federation of 22 February 2006 No. 101 “About federal budget for 2006”]. ConsultantPlus ${ }^{\circledR}$ database software.

Regulation. 2006b. Postanovlenie Pravitel'stva Rossiyskoy Federatsii ot 18 sentyabrya 2006 g. No. 573 “O predostavlenii sotsial'nykh garantiy grazhdanam, dopushchenym $k$ gosudarstvennoy taine na postoyannoy osnove i sotrudnikam structurnykh podrazdeleniy po zashchite gosudarstvennoy tayny" [Governmental regulation of Russian Federation of 18 September 2006 No. 573 "About accordance of social guarantees to citizens admitted to state secrets on constant basis and to servants of secret guarding organization departments”]. ConsultantPlus ${ }^{\circledR}$ database software.

Rosefielde, S. 2005. Russia in the $21^{\text {st }}$ Century: The Prodigal Superpower Cambridge, UK: Cambridge University Press.

Rosstat. 2005. Natsyonal'nye scheta Rossii v 1997-2004 godakh: Stat. Sb. [National Accounts of Russia in 1997-2004: Stat. Compendium]. Moscow: Rosstat.

Rosstat. 2006. Rossiyskiy statisticheskiy ezhegodnik. 2005 [Russian Statistical Yearbook 2005]. Moscow: Rosstat.

Stiglitz, J.E. 2000. Economics of the Public Sector. New York: W.W. Norton.

United Nations. 2002. Transparency in Armaments. United Nations Standardized Instrument for Reporting Military Expenditures: Guidelines. New York: United Nations Department for Disarmament Affairs.

United Nations. 2005. Objective Information on Military Matters, including Transparency of Military Expenditures: Report of the Secretary-General. A/60/159. New York: United Nations.

United Nations. 2006. Objective Information on Military Matters, including Transparency of Military Expenditures: Report of the Secretary-General. A/61/133. New York: United Nations.

Vasilchuk, E. 2006. "Punktom pervym povestki dnya" [As first in agenda]. Rossiyskaya biznes-gazeta, No. 15, p. 7.

WMEAT. 2002. World Military Expenditures and Arms Transfers 1999-2000. Washington, DC: U.S. Department of State. Bureau of Verification and Compliance. 